Pesq. Vet. Bras. 37(4):379-384, abril 2017 DOI: $10.1590 /$ S0100-736X2017000400012

\title{
Pathologic and microbiologic aspects of pet psittacine infected by Escherichia coli and Salmonella Typhimurium ${ }^{1}$
}

\author{
Raul A.S. Siqueira ${ }^{2}$, William C. Maciel², Ruben H. Vasconcelos ${ }^{2}$, Windleyanne \\ G.A. Bezerra ${ }^{2}$, Elisângela S. Lopes ${ }^{2}$, Débora N. Machado ${ }^{2}$, Marcel F. de Lucena ${ }^{2}$ \\ and Ricardo B. de Lucena ${ }^{3}$
}

\begin{abstract}
Siqueira R.A.S., Maciel W.C., Vasconcelos R.H., Bezerra W.G.A., Lopes E.S., Machado D.N., Lucena M.F. \& Lucena R.B. 2017. Pathologic and microbiologic aspects of pet psittacine infected by Escherichia coli and Salmonella Typhimurium. Pesquisa Veterinária Brasileira 37(4):379-384. Laboratório de Estudos Ornitológicos, Universidade Estadual do Ceará, Itaperi, Fortaleza, CE 60740-000, Brazil.Email: raul_spfc15@hotmail.com

The role of Escherichia coli in healthy microbiota of psittacine is controversial, and the presence of Salmonella sp. indicates possible disease. Therefore, this study aimed to identify the presence of E. coli and Salmonella spp. in a psittacine pet that died in Fortaleza, Brazil, correlating pathogenicity aspects of the isolates through the evaluation of lesions and antimicrobial susceptibility. Psittacine pets sent to the Laboratory of Ornithological Studies, State University of Ceará, that died in 2014 and 2015 were necropsied. Fragments of liver, kidneys, intestine, lung, heart, spleen and brain were collected for microbiological and histopathological analyses. Scores were attributed to lesions and isolated strains submitted to antimicrobial susceptibility test. From the seventy necropsied birds, nineteen were positive for E. coli and one for Salmonella Typhimurium. Congestive lesions and lymphoplasmocitic inflammatory infiltrate were observed varying from light to moderate and were the main findings. In the analyzed strains, multidrug resistance against different groups of antibiotics was observed. In conclusion, according to the results, E. coli strains and the Salmonella Typhimurium isolate produced significant lesions in the psittacine pets, and multidrug resistance may hinder treatments with antibiotics used in avian pet medicine.
\end{abstract}

INDEX TERMS: Escherichia coli, Salmonella Typhimurium, colibacillosis, salmonellosis, Psittacidae, anatomopathological features, antimicrobial susceptibility test.

RESUMO.- [Aspectos patológicos e microbiológicos de Psittaciformes de companhia infectados por Escherichia coli e Salmonella Typhimurium.] A participação de Escherichia coli na microbiota saudável de Psicittaciformes e a de Salmonella spp. já indica possível doença. 0 objetivo deste estudo foi pesquisar a presença de E. coli e Salmonella spp. em psittaciformes de companhia na cidade de Fortaleza/ Ceará, traçando os aspectos de patogenicidade destas cepas através das lesões e da sensibilidade antimicrobiana. Foram necropsiados os psittaciformes de companhia encaminha-

\footnotetext{
${ }^{1}$ Received on November 6, 2015.

Accepted for publication on July 13, 2016

2 Laboratório de Estudos Ornitopatlógicos, Universidade Estadual do Ceará (UECE), Av. Silas Munguba 1700, Fortaleza, CE 60740-000, Brazil. *Corresponding author: raul_spfc15@hotmail.com

${ }^{3}$ Laboratório de Patologia Animal, Universidade Federal da Paraíba, Areia, PB 58397-000, Brazil.
}

dos ao Laboratório de Estudos Ornitológicos da Universidade Estadual do Ceará durante o período de 2014 a 2015. No momento da necropsia foram coletados fragmentos de fígado, rins, intestino, pulmão, coração, baço e encéfalo para posterior processamento microbiológico e histopatológico. As lesões foram graduadas e as cepas isoladas submetidas a antibiograma. Das setenta aves necropsiadas, dezenove foram positivas para E. coli e apenas uma para Salmonella Typhimurium. As lesões de congestão e infiltrado inflamatório linfoplasmocitário variaram de leve a moderado, e foram as principais lesões encontradas. Nas cepas analisadas foi constatada multiresistência a diferentes grupos de antibióticos testados. De acordo com os achados, pode-se concluir que os isolados de E. coli e Salmonella Typhimurium produziram lesões significativas em psittaciformes em Fortaleza, Brasil, e a multirresistência pode dificultar o tratamento com antibióticos usados na clínica de aves de companhia. 
TERMOS DE INDEXAÇÃO: Escherichia coli, Salmonella Typhimurium, colibacilose, Salmonelose, Psittacidae, características anatomopatológicas.

\section{INTRODUCTION}

Escherichia coli is an anaerobic Gram negative bacillary bacterium, which is a potential pathogen of birds, named Avian Pathogenic E. coli (APEC) when are responsible for avian colibacillosis. This disease may develop in different forms, such as: colisepticemia, coligranuloma, cellulitis, aerossacullitis, sinusitis, pericarditis, peritonitis, salpingitis, hepatitis, panoftalmitis and osteomyelitis; however respiratory disease followed by septicemia and death is the most frequent process (Janben et al. 2001). The genus Salmonella has two species, S. bongori and S. enterica, which presents six subspecies and 2759 serotypes which cause three distinct diseases: pullorum disease, caused by Salmonella enterica serotype Pullorum; Fowl typhoid, caused by Salmonella enterica serotype Gallinarum; and paratyphoid infection, caused by any of the remaining serotypes (Seo et al. 2000). Both Salmonella sp. and E. coli are not regular members of the intestinal microbiota of psittacine and, therefore isolating these bacteria from asymptomatic or immunosupressed individuals indicates a possibility of disease (Marietto-Gonçalves \& Almeida 2010, Marietto-Gonçalves et al. 2010).

Antimicrobial resistance is the mechanism by which bacteria may overcome the activity of antibiotics, which according to WHO (World Health Organization) mainly occurs due to the indiscriminate use of these drugs important for human and veterinary medicine (Tortora et al. 2012). There is scarce information about antimicrobial resistance and diseases in pet birds, however there are reports involving free-living birds as potential disseminators of $E$. coli and Salmonella sp. resistant to cefalosporins, ampicillin, streptomycin, sulfoxazole and tetracycline isolated from passerines and columbids (Andrés et al. 2013, Poirel et al. 2012, Lopes et al. 2014). This study aimed to perform a survey of $E$. coli and Salmonella spp. from pet psittacine that died during one year and to describe the mains lesions in the affected organs attributing scores, but also to identify the antimicrobial susceptibility profiles of the isolates.

\section{MATERIALS AND METHODS}

Seventy five psittacine pets from Fortaleza, Brazil delivered dead to or that died in the Laboratory of Ornithological Studies from August 2014 to July 2015 were submitted to necropsy to identify the presence of E. coli and Salmonella sp. This study was approved by the Ethics Committee of the Use of Animals of the State University of Ceará under protocol number 1586195/2015 and with the consent from all the owners. The species are shown in Table 1.

Fragments were collected from liver, kidneys, intestine, lung, heart, spleen and brain in formaldehyde and submitted to histopathological analysis. In addition, from each organ, samples were collected with aseptic conditions and material close to the Bunsen burner and placed in tubes containing $5 \mathrm{~mL}$ of buffered peptone water, which were incubated. Then, $0.5 \mathrm{~mL}$ of this broth was transferred to tubes containing brain heart infusion broth and selenite-cystine broth, which were incubated and aliquots were streaked in Petri dishes with MacConkey agar and brilliant green
Table 1. Absolute Frequency and Relative Frequency from species of seventy five psittacine birds necropsied

\begin{tabular}{ccc}
\hline Species & \multicolumn{2}{c}{ Frequency of birds } \\
\cline { 2 - 3 } & $\mathrm{AF}$ & $\mathrm{RF}$ \\
\hline $\mathrm{AA}$ & 13 & 17,33 \\
$\mathrm{AC}$ & 1 & 1,33 \\
$\mathrm{AR}$ & 2 & 2,67 \\
$\mathrm{AZ}$ & 1 & 1,33 \\
$\mathrm{ER}$ & 1 & 1,33 \\
$\mathrm{ET}$ & 11 & 14,67 \\
MT & 25 & 33,33 \\
NH & 19 & 25,33 \\
PH & 2 & 2,67
\end{tabular}

$\overline{\mathrm{AF}}=$ Absolute frequency, $\mathrm{RF}=$ Relative frequency, $\mathrm{AA}=$ Amazona aestiva, $\mathrm{AC}=$ Agapornis roseicollis, $\mathrm{AR}=$ Ara chloptera, $\mathrm{AZ}=$ Amazona amazôni $c a, \mathrm{ER}=$ Eclectus rotates, $\mathrm{ET}=$ Eupsittula cactorum, $\mathrm{MT}=$ Melopsittacus undulates, $\mathrm{NH}=$ Nymphicus hollandicus, $\mathrm{PH}=$ Psephotus haematonotus .

agar. After incubation, a single colony with morphological characteristics compatible with $E$. coli was selected and submitted to the following biochemical tests: triple-sugar-iron (TSI) agar, sulfite-indole-motility (SIM) agar, lysine-iron-agar (LIA), citrate, Voges-Proskauer, methyl red, urease broth and malonate. In addition, a single colony from each plate with morphological aspects similar to Salmonella sp. was selected and submitted to TSI, urease and LIA, followed by rapid slide agglutination test, whenever the biochemical results indicated the presence of this pathogen. If the serological test was positive, the isolate was submitted to the Enterobacteria Laboratory of the Oswaldo Cruz Institute Foundation (Fiocruz) to be confirmed and serotyped.

All the isolates were maintained in nutrient agar in refrigerator until the antimicrobial susceptibility test, which was performed with the isolates being diluted until a turbidity equivalent to 1.0 in McFarland scale was achieved. Then, the inoculum was streaked in plate with Mueller-Hinton agar, to which discs containing the following antibiotics were added: amoxicillin $(10 \mu \mathrm{g})$, ampicillin $(10 \mu \mathrm{g})$, azithromycin $(15 \mu \mathrm{g})$, ciprofloxacin $(5 \mu \mathrm{g})$, doxycycline $(30 \mu \mathrm{g})$, enrofloxacin $(5 \mu \mathrm{g})$, fosfomycin $(200 \mu \mathrm{g})$, gentamycin $(10 \mu \mathrm{g})$, tetracycline $(30 \mu \mathrm{g})$ and sulfazotrim $(25 \mu \mathrm{g})$. After incubation, inhibition zone diameters were measured and compared to standards previously established (CLSI 2012). Multidrug resistance was considered whenever an isolate was resistant to at least two antibiotics of different groups and in all incubation steps afore mentioned, the conditions in bacteriological incubator were temperature of $37^{\circ} \mathrm{C}$ and duration $24 \mathrm{~h}$.

Histopathological procedure was performed at the Animal Pathology Laboratory of the Federal University of Paraíba, where slides of $5 \mu \mathrm{m}$ were prepared and stained with hematoxylin-eosin to be evaluated for the presence of hemosiderosis (HEMO), inflammatory infiltrate (INFINT), congestion (CNGT) and necrosis (NECRO). Lesions were observed and to each a mild $(+)$, moderate $(++)$ or marked (+++) score was assigned according to the intensity.

\section{RESULTS}

From the seventy five investigated psittacine, nineteen were positive for Escherichia coli (nine Melopsittacus undulatus, four Nymphicus hollandicus, three Amazona aestiva, two Eupsittula cactorum and one Psephotus haematono$t u s)$, from which kidneys and liver were the organs with the highest isolation frequency. In addition, from a single Amazona aestiva, a strain of Salmonella enterica serotype Typhimurium was isolated and the results as well as lesions scores are displayed in Table 2. These histopatholo- 
Table 2. Histopathological and bacteriological findings in twenty pet psittacine from Fortaleza, Brazil, with colibacillosis and salmonellosis

\begin{tabular}{|c|c|c|c|c|c|c|c|c|c|c|c|c|c|c|c|c|c|c|c|c|c|}
\hline Organs & Lesions & $\begin{array}{c}1 \\
\mathrm{AA}\end{array}$ & $\begin{array}{c}2 \\
\mathrm{AA}\end{array}$ & $\begin{array}{c}3 \\
\text { AA }\end{array}$ & $\begin{array}{c}4 \\
\mathrm{NH}\end{array}$ & $\begin{array}{c}5 \\
\mathrm{NH}\end{array}$ & $\begin{array}{c}6 \\
\mathrm{NH}\end{array}$ & $\begin{array}{c}7 \\
\text { AA }\end{array}$ & $\begin{array}{c}8 \\
\text { MT }\end{array}$ & $\begin{array}{c}9 \\
\text { MT }\end{array}$ & $\begin{array}{l}10 \\
\text { MT }\end{array}$ & $\begin{array}{l}11 \\
\mathrm{PH}\end{array}$ & $\begin{array}{l}12 \\
\text { ET }\end{array}$ & $\begin{array}{c}13 \\
\text { MT }\end{array}$ & $\begin{array}{l}14 \\
\text { ET }\end{array}$ & $\begin{array}{l}15 \\
\text { MT }\end{array}$ & $\begin{array}{l}16 \\
\text { MT }\end{array}$ & $\begin{array}{l}17 \\
\text { MT }\end{array}$ & $\begin{array}{l}18 \\
\text { MT }\end{array}$ & $\begin{array}{c}19 \\
\mathrm{NH}\end{array}$ & $\begin{array}{l}20 \\
\text { MT }\end{array}$ \\
\hline \multirow[t]{4}{*}{ Liver } & INFINT & ++ & NO & ++ & + & NO & ++ & +++ & NO & + & ++ & + & + & NO & +++ & NO & NO & NO & + & NO & NO \\
\hline & ECR & ++ & NO & ++ & ++ & NO & NO & NO & NO & NO & ++ & NO & NO & NO & ++ & NO & NO & NO & + & NO & NO \\
\hline & NGT & +++ & NO & +++ & +++ & +++ & +++ & +++ & + & +++ & +++ & +++ & + & +++ & +++ & ++ & NO & +++ & + & ++ & +++ \\
\hline & HEMO & ++ & NO & NO & + & NO & + & + & NO & +++ & NO & + & NO & NO & NO & NO & NO & NO & NO & NO & NO \\
\hline \multirow[t]{4}{*}{ Lungs } & INFINT & NO & NO & NO & NO & NO & NO & NO & NO & + & NO & NO & NO & NO & NO & NO & NO & NO & NO & NO & NO \\
\hline & & NO & NO & NO & NO & NO & NO & NO & NO & NO & NO & NO & NO & NO & NO & NO & NO & NO & NO & NO & NO \\
\hline & & +++ & +++ & + & ++ & +++ & NO & +++ & + & +++ & +++ & +++ & ++ & +++ & NO & + & NO & ++ & ++ & +++ & ++ \\
\hline & & NO & NO & NO & NO & NO & NO & NO & NO & NO & NO & NO & NO & NO & NO & NO & NO & NO & NO & NO & NO \\
\hline \multirow[t]{4}{*}{ Kidneys } & INFINT & NO & NO & NO & NO & ++ & ++ & NO & NO & NO & + & NO & NO & NO & NO & NO & NO & NO & NO & NO & NO \\
\hline & & ++ & + & NO & + & + & NO & NO & NO & NO & NO & NO & NO & ++ & NO & NO & NO & NO & NO & NO & NO \\
\hline & & ++ & +++ & +++ & + & ++ & NO & ++ & NO & + & ++ & +++ & NO & ++ & NO & + & NO & + & ++ & + & + \\
\hline & $\mathrm{HI}$ & NO & + & NO & NO & NO & NO & NO & NO & NO & NO & NO & NO & NO & NO & NO & NO & NO & NO & NO & NO \\
\hline \multirow[t]{4}{*}{ Spleen } & NT & + & NO & NO & NA & NA & NA & NO & NA & +++ & NA & NA & NO & NO & NO & NA & NA & NA & NA & NA & NA \\
\hline & & NO & NO & NO & NA & NA & NA & NO & NA & NO & NA & NA & NO & NO & NO & NA & NA & NA & NA & NA & NA \\
\hline & & NO & NO & +++ & NA & NA & NA & +++ & NA & +++ & NA & NA & NO & NO & + & NA & NA & NA & NA & NA & NA \\
\hline & & $\mathrm{N}$ & & NO & NA & NA & NA & + & NA & +++ & NA & NA & NO & NO & NO & NA & NA & NA & NA & NA & NA \\
\hline \multirow[t]{4}{*}{ Intestine } & & NO & & NC & ++ & NO & + & NO & NO & NO & + & NO & NO & NO & NO & NO & +++ & NO & NO & NO & NO \\
\hline & & NO & & & NO & NO & NO & +++ & NO & NO & NO & NO & NO & NO & NO & NO & NO & NO & NO & NO & NO \\
\hline & & ++ & & & + & + & NO & NO & NO & +++ & NO & NO & NO & NO & NO & NO & + & NO & NO & NO & NO \\
\hline & & NO & $\mathrm{N}$ & 1 & NO & NO & NO & NO & NO & NO & NO & NO & NO & NO & NO & NO & NO & NO & NO & NO & NO \\
\hline \multirow[t]{4}{*}{ Encephalus } & INFINT & + & $\mathrm{NC}$ & $\mathrm{NO}$ & NO & NO & NO & NO & NO & NO & NO & NO & NO & NO & NO & NO & NO & NO & NO & NO & NO \\
\hline & & NO & $\mathrm{N}$ & $N$ & NO & NO & NO & NO & NO & NO & NO & NO & NO & NO & NO & NO & NO & NO & NO & NO & NO \\
\hline & & ++ & $\mathrm{N}$ & $\mathrm{N}$ & + & ++ & + & +++ & + & + & NO & + & NO & NO & + & NO & + & + & NO & + & + \\
\hline & & NO & $\mathrm{N}$ & $\mathrm{NC}$ & NO & NO & NO & NO & NO & NO & NO & NO & NO & NO & NO & NO & NO & NO & NO & NO & NO \\
\hline \multirow[t]{4}{*}{ Heart } & INFINT & + & $\mathrm{NC}$ & $\mathrm{NC}$ & NO & NO & NO & +++ & NO & NO & NO & NO & NO & NO & NO & NO & NO & NO & NO & NO & NO \\
\hline & & NO & $\mathrm{N}$ & $\mathrm{NO}$ & NO & NO & NO & + & NO & NO & NO & NO & NO & NO & NO & NO & NO & NO & NO & NO & NO \\
\hline & & $\mathrm{N}$ & $\mathrm{N}$ & $\mathrm{NO}$ & NO & NO & NO & NO & NO & NO & $\mathrm{N}$ & NO & NO & NO & NO & NO & NO & no & NO & NO & NO \\
\hline & & & $\mathrm{N}$ & & NO & NO & NO & NO & NO & NO & NO & NO & NO & NO & NO & NO & NO & NO & NO & NO & NO \\
\hline & & EC & EC & ST & EC & EC & EC & $\mathrm{EC}$ & EC & $\mathrm{EC}$ & EC & EC & EC & EC & $\mathrm{EC}$ & $\mathrm{EC}$ & $\mathrm{EC}$ & $\mathrm{EC}$ & EC & $\mathrm{EC}$ & EC \\
\hline Other lesion & Yes & No & No & No & No & No & No & Yes & Yes & Yes & No & Yes & No & Yes & No & No & No & No & No & No & \\
\hline
\end{tabular}

$\overline{\mathrm{AA}}=$ Amazona aestiva, $\mathrm{NH}=$ Nymphicus hollandicus, $\mathrm{MT}=$ Melopsittacus undulatus, $\mathrm{ET}=$ Eupsittula cactorum, $\mathrm{PH}=$ Psephotus haematonotus INFINT $=$ Inflammatory infiltrate, NECRO $=$ Necrosis, CNGT $=$ Congestion, HEMO $=$ Hemosiderosis, NO $=$ Not observed, NA $=$ Not avaliable, $\mathrm{EC}=$ Escherichia coli, $\mathrm{ST}=$ Salmonella Typhimurium.+ mild,++ moderate,+++ severe

gic lesions were in most cases congestion and inflammatory infiltrates, most frequently in liver and kidneys. The case of salmonellosis presented a multifocal hepatocytes necrosis, accompanied by lymphoplasmocitary and heterophilic inflammatory infiltrates (Fig.1). Hemosiderosis was present only in E. coli cases most frequently in liver, followed by spleen and kidneys; however, lymphoplasmocitary infiltrate was also observed varying from light to moderate (Fig.2). Other simultaneous lesions and/or diseases were observed in six birds (one Amazona aestiva, two Aratinga cactorum and three Melopsittacus undulatus) all positive for E. coli (Table 3), which consisted of traumas, secondary infections and neoplasms.

The antimicrobial susceptibility tests revealed that sulfonamide was the antibiotic to which the isolates presented the most frequent resistance, which was $75 \%$, followed by sulfazotrim $(67 \%)$, both from sulfa group, ampicillin (67\%), nalidixic acid (58\%), tetracycline (50\%), norfloxacin (42\%) and azithromycin (33\%). In three colibacillosis cases, birds were treated with tetracycline, sulfonamide or enrofloxacin, and the respective isolates presented resistance to the same used antibiotics and multidrug resistance. Unfortunately, $66.7 \%$ of the cases did not have information about antibiotics use; however, from five of these, the isolated strains presented resistance to at least one of the tested drugs.
Table 3. Other findings from non-Escherichia coli lesions in six pet psittacine from Fortaleza, Brazil, with colibacillosis

\begin{tabular}{ccc}
\hline Case & Other lesions or disease & Isolated \\
\hline 1 & Granulomatous fungic celomitis & EC \\
AA & Fusiform sarcoma & EC \\
8 & Egg retention & \\
MT & CC \\
9 & Caseous sinusitis & \\
MT & Skin laceration \\
10 & Limb edema & EC \\
MT & & EC \\
ET & \\
14 & ET & \\
\hline AA $=$ Amazona aestiva, MT $=$ Melopsittacus undulatus, ET = Eupsittula cac- \\
torum, EC = Escherichia coli.
\end{tabular}

\section{DISCUSSION}

The role of Esherichia coli in as a commensal member of the regular microbiota of healthy psittacine with regular diet (grains, fruits, vegetables and sprouts) is still controversial, however Salmonella sp. is not consider as a part of the intestinal microbiota of these birds. Therefore, healthy budgerigars (Melopsittacus undulatus) and cockatiels (Nymphicus hollandicus) should present an intestinal microbiota composed mostly by Gram positive bacteria Lamb 


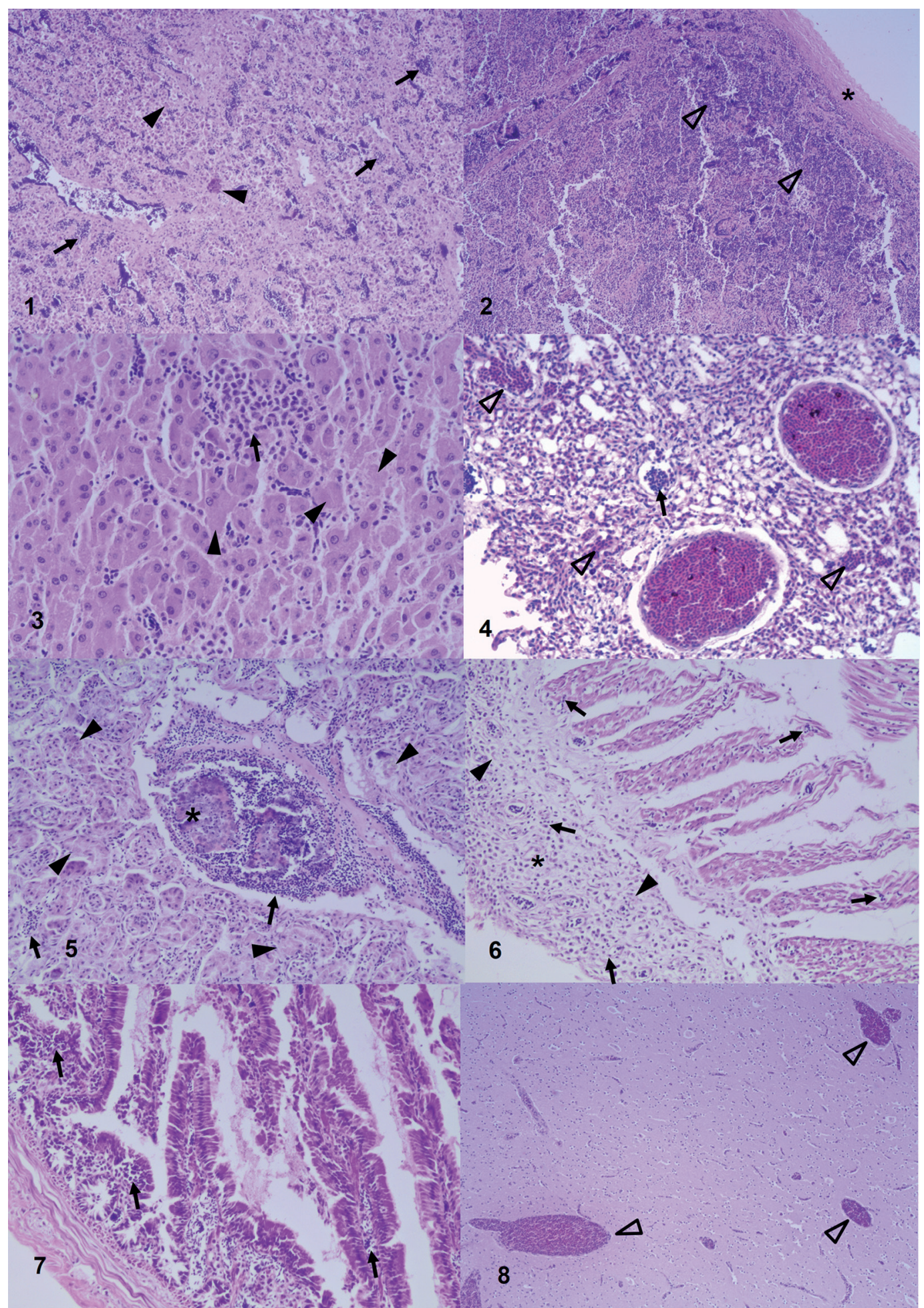

Fig.1-8. Histopathological lesions of salmonellosis and colisepticemia in psittacine pet. (1) Acute hepatitis in Amazona aestiva positive for Salmonella Typhimurium with multifocal necrotizing hepatitis (arrowhead). (2) Lymphoplasmocitary and heterophilic inflammatory infiltrate in liver (slim arrow) and splenitis with congestion and thick capsule (asterisk). HE, obj.10x. (3) Birds positive for Escherichia coli: acute hepatitis in Melopsittacus undulatus with random hepatocyte necrosis (arrowhead) and lymphoplasmocitary infiltrate. HE, obj.40x. (4) Pneumonia in Amazona aestiva with interstitial pulmonary congestion (unfilled arrow) and mixed infiltrate in the interior of alveoli (slim arrow). HE, obj.20x. (5) Nephritis in Nymphicus hollandicus with tubular necrosis (arrowhead), lymphoplasmocitary infiltrate (slim arrow), septic thrombus and basophilic aggregates suggestive of bacterial figures inside vessels (asterisk). HE, obj.20x. (6) Pericarditis in Amazona aestiva with inflammatory lymphoplasmocitary infiltrate among the muscle fibers and pericardium (slim arrow), necrosis and cellular debris (arrowhead) with thickened pericardium (asterisk). HE, obj.20x. (7) Enteritis in Melopsittacus undulates with mixed inflammatory infiltrate in lamina propria (slim arrow). HE, obj.40x. (8) Encephalitis in Amazona aestiva with marked vessel congestion in the white matter (unfilled arrow). HE, obj.20x. 
Table 4. Antimicrobial susceptibility profiles of Escherichia coli and Salmonella Typhimurium strains isolated from different organs of dead pet psittacine

\begin{tabular}{|c|c|c|c|c|c|c|c|c|c|c|c|c|c|c|c|c|c|c|c|c|c|c|c|c|c|c|}
\hline \multirow{2}{*}{$\begin{array}{l}\text { Case and } \\
\text { Isolate }\end{array}$} & \multirow{2}{*}{$\begin{array}{c}\text { Organs } \\
\text { R }\end{array}$} & \multicolumn{2}{|c|}{ AMP } & \multicolumn{2}{|c|}{ AZI } & \multicolumn{2}{|c|}{ CLO } & \multicolumn{2}{|c|}{ CTF } & \multicolumn{2}{|c|}{ FOS } & \multicolumn{2}{|c|}{ GEN } & \multicolumn{2}{|c|}{ NAL } & \multicolumn{2}{|c|}{ NOR } & \multicolumn{2}{|c|}{ POL } & \multicolumn{2}{|c|}{ SUL } & \multicolumn{2}{|c|}{ SUT } & \multicolumn{2}{|c|}{ TET } & \multirow{2}{*}{$\begin{array}{l}\text { Previous } \\
\text { treatment }\end{array}$} \\
\hline & & $\mathrm{S}$ & $\mathrm{R}$ & S & $\mathrm{R}$ & $\mathrm{S}$ & $\mathrm{R}$ & $\mathrm{S}$ & $\mathrm{R}$ & $\mathrm{S}$ & $\mathrm{R}$ & $\mathrm{S}$ & $\mathrm{R}$ & $\mathrm{S}$ & $\mathrm{R}$ & $\mathrm{S}$ & $\mathrm{R}$ & $\mathrm{S}$ & $\mathrm{R}$ & $\mathrm{S}$ & $\mathrm{R}$ & $\mathrm{S}$ & $\mathrm{R}$ & S & $\mathrm{R}$ & \\
\hline \multirow[t]{2}{*}{3 AA ST } & $\mathrm{L}$ & + & - & + & - & - & + & - & + & - & + & - & + & + & - & + & - & - & + & + & - & + & - & + & - & \multirow{2}{*}{$\begin{array}{l}\text { Tetracycline and } \\
\text { Prednizolone }\end{array}$} \\
\hline & $\mathrm{S}$ & + & - & + & - & - & + & - & + & - & + & - & + & + & - & + & - & - & + & + & - & + & - & + & - & \\
\hline $4 \mathrm{NH}$ EC & $\mathrm{K}$ & + & - & + & - & - & + & - & + & - & + & - & + & - & + & - & + & - & + & + & - & + & - & - & + & $\begin{array}{c}\text { Tetracycline and } \\
\text { Sulfonamide }\end{array}$ \\
\hline \multirow[t]{2}{*}{$5 \mathrm{NH} \mathrm{EC}$} & $\mathrm{S}$ & - & + & - & + & - & + & - & + & - & + & - & + & + & - & - & + & - & + & - & + & - & + & - & + & \multirow[t]{2}{*}{ Not informed } \\
\hline & I & - & + & - & + & - & + & - & + & - & + & - & + & + & - & - & + & - & + & + & - & - & + & - & + & \\
\hline $6 \mathrm{NH} \mathrm{EC}$ & $\mathrm{L}$ & - & + & - & + & - & + & - & + & - & + & - & + & - & + & - & + & - & + & - & + & - & + & - & + & Not informed \\
\hline \multirow{2}{*}{9 MT EC } & $\mathrm{L}$ & + & - & - & + & - & + & - & + & - & + & - & + & + & - & - & + & + & - & + & - & - & + & + & - & \multirow{2}{*}{ Ketoprophen } \\
\hline & $\mathrm{K}$ & - & + & - & + & - & + & - & + & - & + & - & + & - & + & - & + & - & + & - & + & - & + & - & + & \\
\hline 10 MT EC & $\mathrm{L}$ & + & - & - & + & + & - & + & - & + & - & - & + & + & - & + & - & - & + & + & - & + & - & + & - & Enrofloxacin \\
\hline 12 ET EC & $\mathrm{L}$ & - & + & - & + & - & + & - & + & - & + & - & + & - & + & - & + & - & + & + & - & + & - & + & - & Not informed \\
\hline 14 ET EC & $\mathrm{K}$ & + & - & + & - & - & + & - & + & - & + & - & + & - & + & + & - & - & + & + & - & + & - & + & - & Not informed \\
\hline \multirow[t]{2}{*}{15 MT EC } & $\mathrm{L}$ & + & - & - & + & - & + & - & + & - & + & - & + & + & - & + & - & - & + & - & + & + & - & - & + & \multirow[t]{2}{*}{ Not informed } \\
\hline & I & + & - & - & + & - & + & - & + & - & + & - & + & - & + & - & + & - & + & + & - & + & - & - & + & \\
\hline 16 MT EC & $\mathrm{L}$ & - & + & - & + & - & + & - & + & - & + & - & + & - & + & - & + & - & + & - & + & - & + & - & + & Not informed \\
\hline 18 MT EC & I & - & + & - & + & - & + & - & + & - & + & - & + & - & + & - & + & - & + & - & + & - & + & - & + & Not informed \\
\hline 20 MT EC & $\mathrm{L}$ & - & + & - & + & - & + & - & + & - & + & - & + & - & + & - & + & - & + & - & + & - & + & - & + & Not informed \\
\hline RF of strains & & & & & 3 & & & & & & & & & 58 &, 3 & & & & & 75 & & & & & 0,0 & \\
\hline
\end{tabular}

$\overline{\mathrm{AA}}=$ Amazona aestiva, $\mathrm{NH}=$ Nymphicus hollandicus, $\mathrm{MT}=$ Melopsittacus undulates, $\mathrm{ET}=$ Eupsittula cactorum, $\mathrm{RF}=$ Relative frequency, $\mathrm{R}=\mathrm{Resistant}, \mathrm{S}=$ Susceptible, AMP = Ampicilin, AZI = Azithromycin, $\mathrm{CLO}=$ Chlortetracycline, $\mathrm{CTF}=$ Ceftiofur, FOS = Fosfomycin, GEN = Gentamicin, NAL= Nalidixic Acid; NOR= Norfloxacin; POL= Polymyxin B, SUT = Sulfazotrim, SUL= Sulfonamide, TET $=$ Tetracycline.

et al. (2014). However, as observed in a study with healthy hispaniolan amazon parrots (Amazona ventralis) in captivity, which had the intestinal microbiota assessed with Gram staining and bacterial culture, E. coli was the most frequent Gram negative rod (23.8\%) (Evans et al. 2014). In addition, a study with three species of Amazona (A. farinosa, A. aesti$v a$ and A. amazônica) and other psittacine with a considerable health risk due to management conditions of illegal wildlife trade, E. coli was isolated from $57.3 \%$ individuals (Hidasi et al. 2013).

In birds that died with suggestive colibacillosis lesions (aerossaculitis, cachexy, pericarditis, perihepatitis, hemorrhage in the intestinal mucosa and accumulation of feces around the cloacae) or symptoms, as observed in this study and in a study with red-spectacled amazon (A. pretrei) parrots, E. coli may be isolated frequently from several distinct organs (Corrêa et al. 2013). Enteropathogenic E. coli has been detected from asymptomatic psittacine from several species, among which Amazona spp. and Eupsittula spp. in captivity (Saidenberg et al. 2012). The frequency of $E$. coli isolation (19\%) from psittacine of illegal wildlife trade or in rehabilitation previous to reintroduction in the wild is more frequent than Salmonella sp. (1.12\%), which was isolated from an A. aestiva as previously described, similar to the findings from this study (Marietto-Gonçalves et al. 2010). There are some reports of Salmonella sp. being isolated from psittacine of conservationist, breeding and rehabilitation facilities, even in Fortaleza, Brazil from the species Ara chloroptera, Amazona aestiva and Melopsittacus undulatus, however this is the first report in Brazil with a pet psittacine (Marietto-Gonçalves \& Almeida 2010, Bezerra et al. 2013, Hidasi et al. 2013, Lopes et al. 2014, Almeida et al. 2015).

Avian colibacillosis aspects were described in a case report with a pet A. aestiva (Marietto-Gonçalves et al. 2007), in which E. coli was isolated from several organs and lesions, which consisted of multiple granulomas and heterophilic infiltrate in lungs, congestion in kidneys, liver and brain, which are similar to the findings in this study. The most frequent lesions of colibacillosis are coagulative liver necrosis, aerossaculitis, granulomas, acute lung hemorrhage and congestion, enteritis with fusion of vili, epithelium hypertrophy and exfoliation, cellulitis with intense heterophilic infiltrate, multinuclear giant cells and fibrin-necrotic plaques; salpingitis with intense follicle necrosis and mixed infiltrate (Crespo et al. 2001, Andrade et al. 2006, Seeley et al. 2014).

The most frequent characteristics of avian salmonellosis are poor body condition, muscular atrophy, granulomas varying from multifocal to coalescent, transmural ulcerative necrosis of the gastrointestinal tract with clear presence of bacterial aggregation inside and outside the lesions, necrotizing hepatitis, interstitial pneumonia, myocarditis, epicarditis and necrotizing encephalitis (Madadgar et al. 2009, Giovaninni et al. 2012). In Australia, a flock of budgerigars with mortality caused by E. coli presented congestion and hemorrhage (Seeley et al. 2014) as the main findings observed, similar to the results from this study, except the encephalitis present in different species of psittacine. The lesions caused by Salmonella Typhimurium in passerines in Switzerland had similar intensity to the ones caused by the strain in this study isolated from the A. aestiva, which was also sever necrotizing hepatitis (Giovaninni et al. 2012). The occurrence colibacillosis in birds with other simultaneous diseases or lesions are frequent, which may serve as an entry port for the infection by E. coli or even Salmonella spp. (Crespo et al. 2001, Seeley et al. 2014).

Elevated rates of resistance to tetracycline or other antibiotics from the same group may occur via transference between microorganisms in the microbiota of birds, which 
may be a direct or indirect risk to the human health (Hu et al. 2013). Resistance to tetracycline in E. coli strains isolated from pet birds have been reported in Australia (13.9\%), from a total of 594 analyzed samples and multidrug resistance was also reported (Blynton et al. 2015). In another study, multidrug resistance to other groups, such as aminoglycosides, quinolones, sulfas and others has been identified in E. coli strains isolated from psittacine.

Similar to other studies involving E. coli and Salmonella sp. isolated from psittacine (Corrêa et al. 2013), antibiotic resistance to tetracycline, sulfonamide and ampicillin presented different results in organs and intestine samples (Case 9 and 14, Table 4). The Salmonella Typhimurium strain isolated in this study presented multidrug resistance to six different antibiotic groups, similar to the strain isolated from parrots in rehabilitation prior to reintroduction in the wild that presented resistance to enrofloxacin, ceflacor, ciprofloxacin and sulfonamide (Marietto-Gonçalves et al. 2010). These findings indicate an indiscriminate use of antibiotics in avian medicine and the occurrence of multidrug resistance involved with failure in antimicrobial therapy.

\section{CONCLUSIONS}

Pet psittacine that died in Fortaleza, Brazil positive for Escherichia coli and Salmonella Typhimurium had colibacillosis and salmonellosis showed mild to moderate lesions and liver was the most affected organ.

Isolated strains presented multidrug resistance and the most frequent was to tetracycline, followed by ampicillin, sulfonamide, sulfazotrim and nalidixic acid; which suggests an ill use of antimicrobials in pet birds.

\section{REFERENCES}

Almeida P.M., Otutumi L.K., Gerônimo E., Messa V., Suenaga S.S., Amaral P.F.G.P., Lima E.T., Vendrame A., Gonçalves D.D. \& Cestari E.D. 2015. Study of the presence of Salmonella spp.and gastrointestinal parasites in excreta from ornamental birds from breeders in the city of Umuruama, Paraná. Afr. J. Microbiol. Res. 9(4):253-257.

Andrade C.L., Ferreira G.F., Franco R.M., Nascimento E.R. \& Tortelly R. 2006. Alterações patológicas e identificação da Escherichia coli como agente causal da celulite aviária em frangos de corte inspecionados em um matadouro em São Paulo. Revta Bras. Clín. Vet. 13(3):139-143.

Andrés S., Vico J.P., Garrido V., Grilló M.J., Samper S., Gavin P., Herrera-León S. \& Mainar-Jaime R.C. 2013. Epidemiology of subclinical salmonelosis in wild birds from a area of high prevalence of pig salmonelosis: phenotypic and genetic profiles of Salmonella isolates. Zoonoses Publ. Health 60:355-365

Bezerra W.G.A., Cardoso W.M., Teixeira R.S.C., Vasconcelos R.H., Machado D.N., Lopes E.S., Albunquerque A.H. \& Rocha-e-Silva R.C. 2013. Survey of Salmonella sp. in budgerigars (Melopsittacus undulatus) in Fortaleza, Brazil. Acta Scient. Vet. 41:1714-1723.

Blynton M.D.J., Pi H., Vangcchia B., Abraham S., Trott D.J., JohnsonJ.R. \& Gordon D.M. 2015. The genetic structure and antimicrobial resistence of Escherichia coli and cryptic clades in birds with diverse human associations. Appl. Environ. Microbiol. 81(15):5123-5133.

CLSI 2012. Perfomance standards for antimicrobial disk susceptibility tests: Approved Standards-Eleventh Edition. CLSI document M02-A11. Clinical and Laboratory Standards Institute, Wayne, PA.

Corrêa I.M.O., Flores F., Schneiders G.H., Pereira L.Q., Brito B.G. \& Lovato M. 2013. Detecção de fatores de virulência de Eschericia coli e análise de Salmonella spp. em psitacídeos. Pesq. Vet. Bras. 33(2):241-246.
Crespo R., Walker R.L., Nordhausen R., Sawyer S.J. \& Manalc R.B. 2001. Salpingitis in Pekin ducks associated with concurrent infection with Tretatrichomonas spp. and Escherichia coli. J. Vet. Diagn. Invest. 13:240-245.

Evans E.E., Mitchell M.A., Whittington J.K. \& Tully Jr T.N. 2014. Measuring the level of agrément between cloacal gram's stains and bacterial cultures in Hispaniolan Amazon parrots (Amazona ventralis). J. Avian Med. Surg. 28(4):290-296.

Giovaninni S., Pewsner M., Hüssy D., Hächler H., Degiorgis M.P.R., Hirschheydt J. von \& Origgi F.C. 2012. Epidemic of Salmonellosis in passerine birds in switzerland with spillover to domestic cats. Vet. Pathol. 50(4):597-606.

Hidasi H.W., Hidasi Neto J., Moraes D.M.C., Linhares G.F.C., Jayme V.S. \& Andrade M.A. 2013. Enterobacterial detection and Escherichia coli antimicrobial resistance in parrots seized from the illegal wildlife trade. J. Zoo Wildl. Med. 44(1):1-7.

Hu G.Z., Pan Y.S., Wu H., Han H., Xu R., Yuan L., Liu J.H. \& Feng J.K. 2013. Prevalence of tetracycline resistence genes and identification of tet(M) in clinical isolates of Escherichia coli from sick ducks in China. J. Med. Microbiol. 62:851-858.

Janben D.W., Schwarz C., Preikschat P., Voss M., Philipp H.C. \& Wieler L.H. 2001. Virulence-associated genes in avian pathogenic Escherichia coli (APEC) isolated from intestinal organs of poultry having died from colibacillosis. Int. J. Med. Microbiol. 291(5):371-378.

Lamb S., Sobczynski A., Starks D. \& Sitinas N. 2014. Bacteria isolated from the skin of congo African grey parrots (Psittacus erithacus), budgerigans (Melopsittacus undulatus), and cockatiels (Nymphicus hollandicus). J. Avian Med. Sug. 28(4):275-279.

Lopes E.S., Cardoso W.M., Albuquerque A.H., Teixeira R.S.C., Salles R.P.R., Bezerra W.G.A., Rocha-e-Silva R.C., Lima S.V.G., Sales R.J.P.F. \& Vasconcelos R.H. 2014. Isolation of Salmonella spp. em Psitaciformes from zoos and a comercial establishment of Fortaleza, Brazil. Arq. Bras. Med. Vet. Zootec. 66(3):965-968.

Madadgar O., Zharaei-Salehi T., Ghafari M.M., Tamai A., Madani A.S. \& Yahyareyat R. 2009. Study of an unusal paratyphoid epornitic in canaries (Serinus canarius). Avian Pathol. 38(6):437-441.

Marietto-Gonçalves G.A. \& Almeida S.M. 2010a. Isolation of Salmonella entérica Serovar Enteritidis in Blue-fronted amazona parrot (Amazona aestiva). Avian Dis. 54:151-155.

Marietto-Gonçalves G.A., Almeida S.M., Lima E.T. \& Andreatti-Filho R.L. 2010b. Detecção de Escherichia coli e Salmonella spp. em microbiota intestinal de Psitaciformes em fase de reabilitação para soltura. Brazilian J. Vet. Res. Anim. Sci. 47(3):185-189.

Marietto-Gonçalves G.A., Lima E.T., Siqueira J.L. \& Andreatti-Fiho R.L. 2007. Colisepticemia em papagaio-verdadeiro (Amazona aestiva). Revta Bras. Saúde Prod. Anim. 8(1):56-60.

Poirel L., Potron A., de La Cuesta C., Cleary T., Nordmann P. \& Munoz-Price S. 2012. Wild coast birds as reservoirs of Broad-Spectrum- $\beta$-Lactamase-producing Enterobacteriaceae in Miami beach, Florida. Antimicrob. Agents Chemoterapy 56(5):2756-2758.

Saidenberg A.B., Teixeira R.H.F., Guedes N.M.R., Allgayer M.C., Melville P.N. \& Benites N.R. 2012. Molecular detection of Enteropathogenic Escherichia coli in asymptomatic captive psittacines. Pesq. Vet. Bras. 32(9):922-926.

Seeley K.E., Baitchman E., Bartlett S., Debroy C. \& Garner M.M. 2014. Investigation and control of an attaching and effacing Escherichia coli outbreak in a colony of captive budgerigars (Melopsittacus undulatus). J. Zoo Wildl. Med. 45(4):875-882.

Seo K.H., Holt T.P.S., Gast R.K. \& Hofacre C.L. 2000. Elimination of early Salmonella Enteritidis infection after treatment with competitive-exclusion culture and enrofloxacin in experimentally infected chicks. Poult. Sci. 79(10):1408-1413.

Tortora G.J., Funke B.R. \& Case C.L. 2012. Microbiologia. $10^{\underline{a}}$ ed. ArtMed, Porto Alegre. 964p.

Veldman K., Tulden P.V., Kant A., Testerink J. \& Mevius D. 2013. Characteristics of Cefotaxime-Resistant Escherichia coli from wild Bird in Netherlands. Appl. Environ. Microbiol. 79(24):7556-7561. 